\title{
Themed Designs in Urban Transformation Areas: The Case of Altinkoy Open Air Museum
}

\author{
Nuriye Ebru Yildiz (Corresponding author) \\ Ankara University, Graduate School of Natural and Applied Sciences, \\ Department of Landscape Architecture, Ankara/Turkey \\ E-mail: neyildiz@ankara.edu.tr
}

\begin{abstract}
The need for housing resulting from increasing population causes urban development areas; it causes a decrease or extinction of the open and green areas within the city boundaries. Therefore, in the context of urban transformation studies carried out with the aim of repair, improvement and renewal of the old or worn-out parts of cities, instead of increasing the amount of green areas of the cities, it is seen that the ecological balances and cultural heritage values of the cities which undermine urban ecology and biodiversity are ignored day by day it is possible to say that increased. In the areas of urban transformation that are constantly changing, it is possible to apply designs with different themes in order to realize nature and climate sensitive landscape planning and design studies and to reach more people.

In this research, the concept of theme was defined in landscape design and classification was made for themed designs in urban transformation areas. Ankara-Altikoy Open Air Museum, which is the main material of the study and located in Altindag District of Ankara City, can be shown as an example of a themed landscape design in the area of urban transformation. In order to determine the effect of urban transformation areas on green areas in the research area and its vicinity, NDVI analysis was performed with ArcGIS 10.2 software and the change in land cover was expressed by spatial maps. In addition to the NDVI analysis, the design criteria of the research area were examined within the scope of themed landscape designs; In order to determine the contribution of Altinkoy to Ankara City identity and the tourism potential, the internal factors / strengths and weaknesses and external factors/opportunities and threats of the area were determined by using SWOT Analysis method.
\end{abstract}

Keywords: Urban transformation, themed design, Altinkoy Open Air Museum

DOI: $10.7176 / J S T R / 5-4-01$

\section{Giriş}

Kentsel dönüşüm, kentsel sorunlara çözüm üretmek amacıyla, değişime uğrayan bir bölgenin ekonomik, fiziksel, sosyal ve çevresel koşullarına kalıcı bir çözüm sağlamaya çalışan kapsamlı bir vizyon ve eylem olarak ifade edilmektedir (Thomas, 2003). Keleş (2004) ise, kentsel dönüşümü, bir kentin tümünün veya belli kesimlerinin değişmesi, başka bir biçime girmesi şeklinde tanımlamakta, kent plancıları arasında bu kavramın, kentlere yeni yerleşim alanlarının eklenmesinden farklı olarak, kentin geçmişten beri var olan kesimlerinin içyapısında ve başka yerleşim birimleri ile olan ilişkilerinde meydana gelen değişimleri anlatmak için kullanıldığını ifade etmektedir (Polat ve Dostoğlu, 2007). Bu süreçte kentsel dönüşüm uygulamaları kapsamında; kentsel yenileme, yeniden canlandırma, yeniden yaratma, yeniden geliştirme veya imar, yeniden yapılandırma, koruma, soylulaştırma gibi farklı çalışmalar gündeme gelmektedir. Ancak artan nüfus ile birlikte ortaya çıkan barınma ihtiyacı sonucunda kentsel dönüşüm alanlarının plansız gelişimine ve kent sınırları içinde yer alan açık ve yeşil alanların azalmasına veya yok olmasına neden olmaktadir.

Türkiye'de kentsel dönüşüm olgusu farklı dönemlerde farklı yapısal, bağlamsal, sosyo-ekonomik, yönetsel ve fiziksel yaklaşımlara bağlı olarak değişim göstermiştir (Tablo 1). Kentsel dönüşüm uygulamaları ve araçları yerel koşullar ve küresel akımların etkisi ile belirlenmiştir. Bu müdahale biçimleri, uygulama sürecinde ve sonrasında mekâna sadece fiziksel müdahale olmaktan daha kapsamlı sosyo-ekonomik boyutları içerecek biçimde çeşitlilik göstermiştir. Farklı fiziksel müdehaleler Dünya'da değişen planlama yaklaşımları ve bunun Türkiye'ye yansımaları biçiminde olmuştur (Ataöv ve Osmay, 2007). Dolayısı ile kentlerin eskimiş veya eskimeye yüz tutmuş kesimlerinde onarım, iyileştirme ve yenileme amacı ile gerçekleştirilen kentsel dönüşüm çalışmaları kapsamında, kentlerin yeşil alan miktarını arttırmak yerine kent ekolojisine ve biyoçeşitliliğe zarar veren, ekolojik dengelerin ve kültürel miras değerlerinin gözardı edildiği ve yanlış alan kullanım kararlarını içeren uygulamaların gün geçtikçe arttığını söylemek mümkündür.

1 I $\mathrm{P}$ a g $\mathrm{e}$

www.iiste.org 
Tablo 1. Kentsel dönüşüm uygulamaları (Ataöv ve Osmay, 2007)

1950-1980

1. Gecekondu bölgelerinin sağlıklaştırılması; 2. Kent merkezinin çöküntü alanına dönüşümü; 3. Gecekondu alanlarının yeniden yapılandırılması; 4. Bu alanlarda kentsel yenileme
1980-2000

1. Yaşam kalitesi düşmüş ve riskli alanlarda kentsel yenileme; 2. İyileştirmeye yönelik sağlıklaştırma ve sslah-imar uygulamaları; 3 . Tarihi değeri olan alanların korunmasi ve soylulaştırılması

\section{SONRASI}

1. Kentsel alanlarda yenileme; 2. Apartman alanlarının iyileştirilmesi; 3 . Yeni siteler ve kapalı yerleşim alanlarının yeniden geliştirilmesi; 4. Tarihi konut alanların soylulaştırılması

Sürekli değişim ve dönüşüm gösteren kentsel alanlarda, doğa ve iklim duyarlı peyzaj planlama ve tasarım çalışmaları gerçekleştirmek ve daha fazla kişiye ulaşabilmek amacı ile farklı ve öncü tasarımlara başvurulabilmektedir. Bu nedenle son yıllarda gündemde olan "tema" kavramı, diğer sanat dallarında olduğu gibi peyzaj tasarımında da önemli bir yer tutmaktadır. Sanatçının konuyu oluşturan öğeleri kullanarak izleyiciye aktarmaya çalıştığı duygu olan tema; kentsel dönüşüm alanlarına yeni ve farklı bir bakış açısı kazandırırken, toplum içinde eğlenceli, dinamik ve akılda kalıcı olabilmektedir. Bu amaçla yapılan tasarımlarda pek çok değişik tema üzerinde durulabilmektedir. Kimi zaman eğitim, sağlık, bitki teması ile tasarlanmış peyzajlara rastlanırken, kimi zaman bir şehrin birebir kopyasının, sokaklarının hatta köprülerinin görülebileceği ve o şehire ait kültürel niteliklerin yansıtıldığı temalarla da karşılaşmak mümkün olmaktadır (Yurttaş, 2010). Türkiye'de ve Dünya'da pek çok örneğine rastlanabilen temalı tasarımların, kentsel ve kırsal alanlara ve turizm sektörüne sağladığı katkıların yanı sıra kentsel dönüşüm alanlarına da canlılık ve eğlenceli mekânlar kazandırması mümkündür.

Mimarlık, peyzaj mimarlığ 1 ve görsel sanatlarda ele alınan tema kavramı, diğer sanat dallarında olduğu kadar olması beklenen ve aranan bir durum değildir. Bugün yapılan peyzaj tasarım çalışmalarında da tema zorunluluk teşkil etmemekte, ancak özellikle kentsel çevrelerin kimlik ve estetik değerleri açısından önemli bir yer tutmaktadır. Kentlerin karakterini ortaya koyan doğal, kültürel ve tarihi nitelikleri ile o çevrenin iklimsel ve coğrafi özellikleri arasındaki etkileşim sonucu ortaya çıkan mekân-insan ilişkisi, kentsel dokuyu; yani kent kimliğini oluşturmaktadır. Bu nedenle kentsel dönüşüm alanlarının peyzaj tasarımında ele alınan tema kavramının, kent kimliğine katkı sağlaması ve kentin estetik değerlerini arttıracak niteliklere sahip olması gerekmektedir. Diğer bir ifade ile kentsel alanlar için tasarlanan tematik mekânlarda, kullanılan canlı ve cansız malzemenin yanında, kent kimliğini koruyan sürdürülebilir peyzaj tasarım yaklaşımlarının da benimsenmesi, kentin sahip olduğu nitelikler açısından büyük önem taşımaktadır. Bu yaklaşımları benimseyen tematik peyzaj tasarımları sayesinde; kentlerin doğal, kültürel ve tarihi değerleri korunup, yaşam kalitesi artırılırken, çevre ve kent estetiği bağlamında da katkılar sağlanmış olacaktır.

$\mathrm{Bu}$ araştırmada, peyzaj tasarımında tema kavramı tanımlanmış ve temayı yönlendiren faktörler irdelenmiştir. Çalışmanın ana materyalini oluşturan ve Ankara Kenti'nin Altındağ İlçesi'nde yer alan Ankara-Altıköy Açık Hava Müzesi, kentsel dönüşüm alanında gerçekleştirilmiş bir temalı peyzaj tasarımına örnek olarak gösterilebilmektedir. Araştırma alanı ve yakın çevresinde, kentsel dönüşüm alanlarının yeşil alanlara olan etkisinin belirlenmesi amacı ile ArcGIS 10.2 yazılımı ile NDVI analizi yapılmış ve arazi örtüsündeki değişim mekânsal haritalar ile ifade edilmiştir. NDVI analizinin yanı sıra araştırma alanının tasarım kriterleri, temalı peyzaj tasarımları kapsamında irdelenmiş; Altınköy’ün Ankara Kenti’nin kimliğine olan katkıları ve turizm potansiyelinin belirlenmesi amacı ile SWOT Analizi yönteminden yararlanılarak, alanın içsel faktörleri/güçlü ve zayıf yönler ve dışsal faktörleri/fırsatlar ve tehditler saptanmıştır. Çalışma alanının içsel ve dışsal etkenleri dikkate alınarak gerçekleştirilen analizde, alanın var olan güçlü yönleri ve fırsatları etkin biçimde değerlendirilmiş; tehditlerin ve zayıf yönlerin ise geliştirilme olanakları irdelenmiştir.

Özellikle kentsel dönüşüm alanlarının tasarımında bireyler için gereken yeşil alan miktarının sağlanması gerekmektedir. Dünya Sağlık Örgütü, kentte kişi başına düşen yeşil alan miktarının en az $9 \mathrm{~m}^{2}$ olması gerektiğini, $10-15 \mathrm{~m}^{2}$ ise ideal olduğunu belirtmektedir. Gelişmiş ülkelerde kişi başına düşen yeşil alan ortalama $20 \mathrm{~m}^{2}$ iken; Türkiye'de 1 ila $9 \mathrm{~m}^{2}$ arasında değişmektedir (Erzurumlu-Sandal ve ark. 2017). Bu

2 I P a g e

www.iiste.org 
nedenle, kentsel dönüşüm alanlarının temalı tasarımlar kapsamında değerlendirilerek, kişi başına düşen yeşil alan miktarının en az $9 \mathrm{~m}^{2}$ olacağı kentsel dönüşüm alanlarının tasarlanması önemli bir konudur. Çalışma, kişi başına düşen açık ve yeşil alan miktarının $9 \mathrm{~m}^{2}$ den az olduğu kentlerde gerçekleştirilen kensel dönüşüm çalışmaları kapsamında yenilenen kent alanlarının, temalı açık ve yeşil alanlara dönüşümünü önermesi açısından özgün değere sahiptir.

\section{Peyzaj Tasarımında Tema}

Türk Dil Kurumu'nun (2006) tanımına göre tema kavramı; "ası1 konu, temel motif, ana konu" olarak ifade edilmektedir. Sümerkan (2011)'a göre tema; "bir sanat eserine hâkim olan, onda işlenen, geliştirilen ana düşünce ya da görüştür”. Tematik mekân tasarımı, tasarlanmış olan mekâna özgünlük, zenginlik, farklılık katan bir olgudur. Bir mekâna tematik unsurlar katmak düşünsel derinliğini arttırmanın yanı sıra mekânın akılda kalmasına da katkı sağlamaktadır. Mekânın kullanıcısı ve tasarımcısının iliş̧i kurmasını sağladığı yapıların akılda kalmasına, unutulmaz kııımasına da yardımcı olmaktadır. Tematik mekân tasarımında, tasarımcıya yol gösteren, tasarımını oluşturmasını sağlayan en önemli veriler; mekânın kullanılma amacı, kullanıcı özellikleri ve hedeflenen imge çalışmasıdır. Tasarımcı, mekânı kullanacak kişi/kişilere ait verileri, planlanmış tema çerçevesinde değerlendirip, tasarımına aktarmaktadır (Altın, 2015).

Temayı oluşturan ifade dilinin anlaşılabilirliğinin önemli olmasının yanı sıra, teknik olanaklarla da bu dilin desteklenmesi gerekmektedir. Peyzaj mimarları, bu noktada peyzaj tasarımının kent kimliğini şekillendiren kavramların en önemlilerinden biri olduğunun bilincinde olarak, kullanıcıya aktarmaya çalış̧ıkları duyguları, tasarımlarının temasını oluşturan öğeleri kullanmak sureti ile tasarladıkları doğal ve yapay çevrelerde ifade etmektedirler. Diğer bir ifade ile kentsel/kırsal bir çevrede geçirilen belirli bir zaman süresince duyu organları ile algılanan heykeller, kentsel donatı elemanları, sokaklar, caddeler ve diğer mekân bileşenleri ile bu mekândan çıktıktan sonra aklımızda kalan olgular, düşünceler mekânın temasını vermekte ve kişinin zihninde kent kimliğine ilişkin belirli bir imajın oluşmasına da katkı sağlamaktadır (Codur, 2010).

Altın'ın (2015) ifadesi ile tasarımda tema; "genellikle tarihten, farklı kültürlerden ve düşsel bir dünyadan hareketle" belirlenmekte ve bu doğrultuda "restoranlar, müzeler, havaalanları, parklar ve çeşitli yerleşim birimleri" temalı olarak tasarlanabilmektedir. O halde ele alınan tema kavramı, sadece donatı ölçeğinde değil, yapı, park, bahçe, sokak, mahalle, kent ölçeğinde de ele alınabilmektedir. Bu kapsamda gerçekleştirilen temalı tasarımlarda, renk, doku, malzeme gibi bu alana ait tüm görsel tasarım öğelerinden yararlanılabilmektedir.

Tasarlanan mekânlarda, tema olgusunu vurgulayan, gerçekleştiren ya da güçlendiren faktörler söz konusudur. Tematik mekân kurgusunu oluşturan bu faktörler, tasarımcı tarafindan belirlenip kurgulanacağı gibi mekânları kullanan kişilerin ihtiyaçları ve beğenileri doğrultusunda da ortaya çıkarabilmektedir. Tema kavramını yönlendiren faktörler; malzeme, renk/ışık, bitki, sanat akımı/dönem veya kavram kullanımı, külttür ve coğrafya etkisi olmak üzere yedi sınıfta değerlendirilmektedir (Yurttaş, 2010).

Malzeme kullanımı: Tasarlanmış çevreleri ya da bu çevreler içinde bulunan elemanları tanımlarken, bu nesneler ile ilgili dikkat edilmesi gereken en önemli unsur kullanılan yapı malzemelerinin türüdür. $\mathrm{Bu}$ anlamda malzeme bir mekânı tanımlayan, mekâna karakter kazandıran, en temel özelliklerden biridir (Yurttaş, 2010). Diğer bir ifade ile temalı tasarımlarda kullanılacak malzemelerin teknik ve estetik özellikleri, kullanıcıya verilecek olan ana konuyu yani tasarımın temasını ifade edebilir nitelikte olması gerekmektedir.

Renk/Işık Kullanımı: Renk, ışık ile birlikte var olarak, mekânın algılanmasında en etkin faktörlerden birini oluşturmaktadır (Yurttaş, 2010). Tasarımın kurgusunda tercih edilen renkler, kullanıcıların duygusal, zihinsel ve fiziksel dünyasını etkilemektedir. Bazı renkler pozitif etkiler yaratırken kimi zaman insanı olumsuz bir ruh haline yönlendirecek, iç daraltıcı, sıkıcı bir duygu yaratmaktadır. Bu özellikleri ile renkler, uyarıcı ya da durgunluk yaratıcı, yapıcı ya da yıkıcı, itici ya da çekici duygular yaratabilmektedir. Renk, görsel dengenin sağlanmasında, farklı elemanların bütün olarak algılanmasında son derece önemli bir rol oynamaktadır (Altın, 2015). Bir rengin algılanmasında yer ve zaman özellikleri, kişisel algı, alışkanlıklar ve tercihler önemli olsa da asıl önemli olan ışıktır (Abercrombie, 1990).

Sanat akımı veya dönemi kullanımı: Tasarım ve sanatta, belirli bir tarihsel dönemde aynı fikir ve sanat anlayışına sahip sanatçıların oluşturduğu grup veya gruplar, anlayış bakımından yeni fikirler ve

3| P a g e www.iiste.org 
farklılıklar ortaya koyarak "sanat akımları"nı ortaya çıkarmışlardır. Bu akımlar, bulundukları dönemde var olan tüm sanat dallarını etkileyerek yeni bir düşünce ortaya koyarak, toplumun günlük yaşamında, özellikle de kültürel yaşamında önemli değişiklikler meydana getirmiştir. Akımlar birbirini ortaya çıkarmış; çoğu sanat akımı bir önceki akıma tepki olarak doğmuştur (Yurttaş, 2010).

Bitki Kullanımı: Peyzaj tasarımlarının en önemli materyali olan bitkiler, estetik ve fonksiyonel amaçlarla farklı mekânlara, farklı anlamlar katmaktadırlar. Tema olarak bitkilerin kullanıldıkları tasarımlarda, bitkilerin birbirleri ve yapısal materyallerle olan ilişkilerini istenilen şekilde düzenleyebilmek için bitkisel tasarım ilkelerinin yanı sıra bitkilerin ölçü, form, doku, renk gibi mevsimlere göre değişim gösteren genel özellikleri de büyük önem taşımaktadır. Bitkisel materyalin bu estetik özelliklerinden yararlanarak, farklı kullanıcı kitlelerine hitap edecek, belirli temalara sahip peyzajlar tasarlanabilmektedir. Bitki materyali, bitki teması ile tasarlanmış mekânlarda, eğitim, sağlık, sergileme gibi pek çok amaçla kullanılabilmektedir. Bugün, dünyada yapılan bitki temalı tasarımlarla botanik bahçeleri, terapi ve iyileştirme bahçeleri, tıbbi ve aromatik bahçeler, arboretumlar oluşturulmaktadır.

Kültürel etmenler: Kültür insan için kendi toplumunun bir mirasıdır. Çünkü her kuşak kendisinden önceki kuşaklardan veya nesillerden öğrendiklerini ve de kendisinin kültüre kattıkları ile birlikte bir sonraki nesilere aktarmaktadır. Her kültür, kendi öğeleri ile tutarlı ve dengeli bir bütünlük oluşturmaktadır. Toplumlarda aile, hukuk, sanat, ekonomik şartlar, örf ve adet, töreler, ahlaki değer yargıları adeta bir bütün halindedir. Toplumu oluşturan bireyler bağlı bulundukları kültürler doğrultusunda bir yaşam tarzına sahiptirler (Altın, 2015). Tasarımcılar da bu kültürel özellikler doğrultusunda temalı mekânlar yaratabilmektedirler. Kullanıcı talepleri ve tasarım alanının çevresel özellikleri göz önünde bulundurularak, ele alınan tema doğrultusunda belirli bir toplumun kültürel özellikleri tasarım alanına yansıtılabilmektedir. Bir toplumun geleneksel el sanatları, geleneksel mimarisi, üretim biçimi ve diğer kültürel niteliklerinin izlerini taşıyacak kültür temal mekânlar oluşturulabilmektedir. Kırsal ve kentsel alanlarda kültür teması ile oluşturulmuş peyzajlar, mekâna kimlik kazandıracak değerler yaratılmasına katkı sağlamaktadırlar. Tasarımın ana öğesini oluşturan toplumun kültürel değerlerinin mekâna yansitılması ile o topluma ilişkin niteliklerin geçmiş dönemlerden gelecek nesillere aktarılması mümkün olmaktadır.

Coğrafi etmenler: Toplumlar, yaşadığı yerkürenin doğal, fiziksel ve beşeri şartları ile sürekli etkileşim halindedir. Bu etkileşim kimi zaman olumlu kimi zamanda olumsuz koşulların ortaya çıkmasına neden olmaktadır. Yaşanılan çevrenin dünya üzerindeki konumu ve iklimi, yaşam biçimini doğrudan etkilemektedir (Yurttaş, 2010). Bir diğer ifade ile yaşanılan çevrenin coğrafi ve iklimsel özellikleri, kentsel ve kırsal çevrelerin tasarımları üzerinde etkilere sahiptir. Tematik mekân oluşumunda da coğrafyanın etkisi, mekânların bulundukları doğal çevrenin fiziki özelliklerini bünyelerinde bulundurmaları sonucunda oluşmaktadır. Coğrafi bölgenin fiziki şartlarının, mekânın bileşenlerine, kullanılan malzeme yapısına, yöresel elemanların mekân içindeki yerine doğrudan etkisi bulunmaktadır (Yurttaş, 2010).

Kavram kullanımı: Tasarımcılar bir mekân yaratırken, tasarımlarını genellikle bir kavram üzerine kurgulamaktadırlar. Bu kavram, toplum tarafindan benimsenen bir obje, bir kişilik, bir nesne ya da ilgi çekici bir hikaye olabilmektedir. Tematik mekân olgusunun bir kavram kullanarak yaratıldığı mekânlar, örneklerle çoğaltılabilmektedir; dış mekânda çeşitli çiçek resimleri, figürler veya illüstrasyonlar kullanılarak, çiçek temalı bir mekân yaratılabilmektedir. İnsanların sürekli merak ettikleri bir kavram olan uzay, bir mekânın temasını oluşturabilmektedir. Kadın sağlığı üzerine hizmet veren bir sağlık biriminde bahçe, kadın teması ile oluşturulmuş kadın heykelleri ile düzenlenebilmektedir (Yurttaş, 2010). Kimi zaman tasarımcılar mizah konusunu ele almak isteyebilirler. Bu kapsamda yaptıkları çalışmalarda, toplumu eğlendiren, güldüren ama bu süreçte düşünmeye sevk eden mizah temalı objelere, sokak sanatı çalışmalarına, heykellere yer verebilmektedirler.

\section{Materyal ve Yöntem}

Çalışmanın ana materyalini oluşturan ve Ankara Kenti'nin Altındağ İlçesi'nde yer alan Ankara-Altıköy Açık Hava Müzesi, 3958'38.00" Kuzey enlemleri ile 3257'23.10" Doğu boylamları arasında yer almaktadır (Şekil 1). Araştırma kapsamında envanter toplama, verilerin analizi ve değerlendirilmesi

4 | P a g e www.iiste.org 
amacı ile temin edilen sayısal, sözel ve görsel veriler araştırmanın diğer materyallerini oluşturmaktadır. Bunlar;

- Altınköy Açık Hava Müzesi ve yakın çevresinin Google Earth 2018 uydu görüntüsü;

- 2010 yılı Temmuz ayı Landsat 7 ETM+ uydu görüntüsü ile 2018 yılı Temmuz ayı Landsat 8 OLI/TIRS uydu görüntüsü;

- Kuramsal temeller, yöntem ve araştırma bulguları ile ilgili ulusal literatür verileridir.

Kentsel gelişim alanlarında ekolojik etkinin değerlendirilmesi amacı ile gerçekleştirilen yöntem araştırmasında, ulusal ve uluslararası cbs tabanlı peyzaj planlama yaklaşımları irdelenmiş ve 6 aşamadan oluşan bir çalışma gerçekleştirilmiştir (Tablo 2). Araştırma alanı olarak belirlenen Altınköy Açık Hava Müzesi; kentsel dönüşüm alanında gerçekleştirilmiş bir temalı peyzaj tasarımına örnektir. Kuramsal temellere ve çalışma alanına ilişkin gerçekleştirilen çalışmada; literatür taraması ve envanterlerin toplanması amacı ile ulusal ve uluslararası literatür verilerinin ve harita gibi görsel verilerin yanı sıra coğrafi bilgi sistemleri ile edinilen bulgulardan yararlanılmıştır. Çalışmaya altlık sağlaması amacı ile cbs ortamında sayısal yükseklik modeli (DEM) ve kabartma (hillshade) haritası oluşturulmuş̧ur. Araştırma kapsamında, kentsel gelişim alanlarında ekolojik etkinin değerlendirmesi amacı ile coğrafi bilgi sistemleri yazılımlarından ArcGIS 10.2 ve Landsat 7 ETM+ ile Landsat 8 OLI/TIRS uydu görüntülerinin kullanımı ile mekânsal ve yazılı veriler ilişkilendirilmiş, kentsel dönüşüm alanlarının yeşil alanlara olan etkisinin belirlenmesi amacı ile NDVI analizi yapılmış ve arazi örtüsündeki değişim mekânsal haritalar ile ifade edilmiştir. NDVI analizinin yanı sıra Altınköy’ün Ankara Kent kimliğine olan katkıları ve turizm potansiyelinin belirlenmesi amacı ile SWOT Analizi yönteminden yararlanılarak, alanın içsel faktörleri/güçlü ve zayıf yönler ve dışsal faktörleri/firsatlar ve tehditler saptanmıştır.

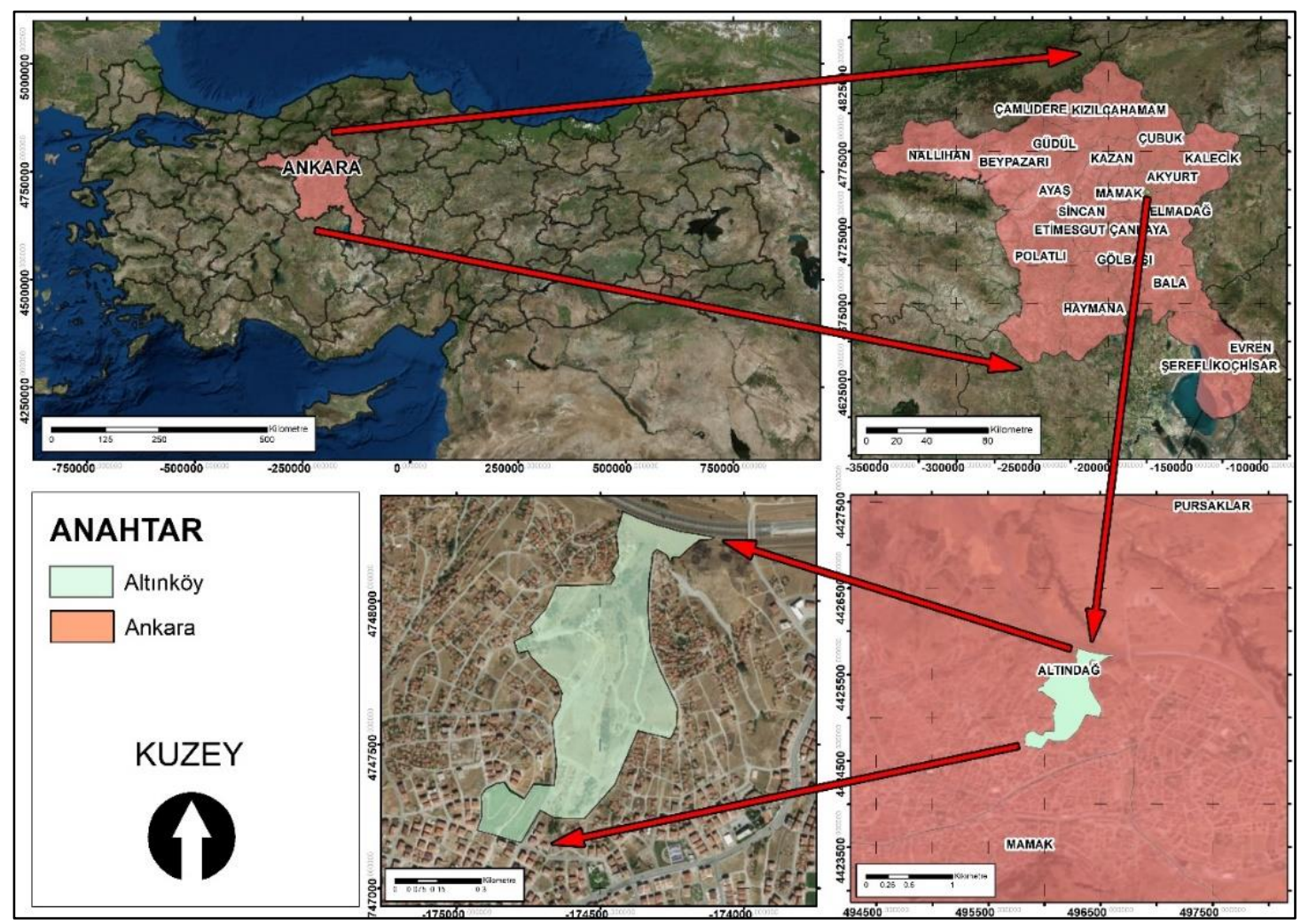

Şekil 1. Altınköy Açık Hava Müzesi coğrafi konum haritası (Orijinal, 2019) 
Tablo 2. Çalışmanın aşamaları

\begin{tabular}{|c|c|c|}
\hline AŞAMA & KAPSAM & AÇIKLAMA \\
\hline $\begin{array}{c}1 . \\
\text { AŞAMA }\end{array}$ & $\begin{array}{l}\text { Araştırma alanı sınır, } \\
\text { amaç ve kapsamının } \\
\text { belirlenmesi }\end{array}$ & Altınköy Açık Hava Müzesi ve yakın çevresi \\
\hline $\begin{array}{c}2 . \\
\text { AŞAMA }\end{array}$ & $\begin{array}{l}\text { Literatür taraması ve } \\
\text { envanter toplama }\end{array}$ & $\begin{array}{c}\text { Kuramsal temeller, yöntem ve araştırma bulgularına ilişkin } \\
\text { verilerin derlenmesi }\end{array}$ \\
\hline $\begin{array}{c}3 . \\
\text { AŞAMA }\end{array}$ & $\begin{array}{c}\text { Yöntemin } \\
\text { belirlenmesi }\end{array}$ & $\begin{array}{l}\text { Arazi örtüsü değişiminin tespit edilmesi - NDVI } \\
\text { SWOT Analizi }\end{array}$ \\
\hline $\begin{array}{c}4 . \\
\text { AŞAMA }\end{array}$ & $\begin{array}{l}\text { Coğrafi veri } \\
\text { tabanının üretilmesi }\end{array}$ & $\begin{array}{l}\text { Konum belirleme (Google Earth } 2018 \text { uydu görüntüsü) } \\
\text { Yükseklik Modeli (DEM) } \\
\text { Landsat } 7 \text { ETM+ ve Landsat } 8 \text { OLI/TIRS uydu görüntüleri }\end{array}$ \\
\hline $\begin{array}{c}\mathbf{5 .} \\
\text { AŞAMA }\end{array}$ & Analiz & $\begin{array}{c}\text { Normalize Edilmiş Bitki Örtüsü İndeksi (NDVI) Analizi, } \\
\text { SWOT Analizi }\end{array}$ \\
\hline $\begin{array}{c}\text { 6. } \\
\text { AŞAMA }\end{array}$ & Sonuç & $\begin{array}{l}\text { Kentsel dönüşüm alanının arazi örtüsü değişiminin tespit } \\
\text { edilmesi } \\
\text { Altınköy’ün turizm potansiyelinin belirlenmesi }\end{array}$ \\
\hline
\end{tabular}

\section{Araştırma Bulguları}

Bu bölümde, Altınköy Açık Hava Müzesi temalı tasarımlar kapsamında değerlendirilmiş; Altınköy Açık Hava Müzesi'ndeki arazi örtüsü değişimi tespit edilmiş ve Altınköy Açık Hava Müzesi’nin turizm potansiyeli belirlenmiştir.

\subsection{Altınköy Açık Hava Müzesi}

Altınköy, Ankara Kenti'nin Altındağ İlçesi'nde yer alan ve 1930 yıllarından itibaren Anadolu'nun farklı coğrafi bölgelerinde yer alan kırsal yerleşimlerin biçim ve karakterini yansıtan ve yaklaşık 500 dönüm arazi üzerine kurulmuş bir açık hava müzesidir. Altınköy’deki en önemli alan kullanımları ve yapısal öğeleri; cami, çamaşırhane, okul, bakkal, köy evleri, yel ve su değirmeni, asma köprü, köy kahvesi, atölyeler, firın ve tarımsal üretim biçimlerinin sergilendiği yaylalar olarak ifade edilmektedir. Kırsal yerleşim karakterine sahip olan bu açık hava müzesinde, buğday tarlası, sebze, meyve tarlaları, meyve ağaçları, ahır ve kümes gibi doğal ve kültürel peyzaj özelliklerine yer verilmesinin yanı sıra koyun, kuzu, at, köpek, kedi, kuş, geyik, ceylan, arı, horoz, tavuk gibi fauna varlıklarına da barınma olanağı sağlamakta; geleneksel gıda ürünlerinin, sanatsal ve el yapımı ürünlerin üretildiği ve satışa sunulduğu nalbant, kalayc1, dokumacı, demirci, değirmen atöyleleri de yer almaktadır.

Çantı Ev: Açık Hava Müzesi'nin en önemli yapısal unsurlarından biri olan “Çantı Ev”ler; özellikle ormanlık bölgelerde ağaç gövdelerinin üst üste yığılması ile inşa edilmiş geleneksel konut yapılarıdır. Bu yapım tekniği, yontulmamış ya da kereste haline getirilmiş uzun ahşap öğelerin geçmeler aracılığıyla birbiri üstüne eklenmesi biçiminde uygulanmaktadır. Türkiye de dâhil tüm dünyada ormanlık yörelerde görülmekte olan çantı yapı tekniği, Türkiye'de özellikle Doğu Karadeniz bölgesi’ndeki serander yapılarının inşa edilmesinde kullanılmaktadır. 1950'li yıllara kadar, Kuzey Anadolu'da, kırsal yerleşim alanlarında yer alan konutların inşasında kullanılan bu yöntem, 1950'li yıllardan sonra betonarme yapılara yerini bırakmıştır (Anonim, 2019). Altınköy’de Berberler Konağı, Emdiler Konağı, Hacı Osmanoğlu Konağı, Katırcı konağ1, Ayvacık Konağ1, Döngeller Konağ1, Akmanlar Konağ1, Dokuma Atölyesi, Demirci ve Kalaycı Atölyesi, Hızar, Köy Kahvesi ve diğer yayla evleri çantı yapım tekniği ile inşa edilmiş yapılardır (Şekil 2).

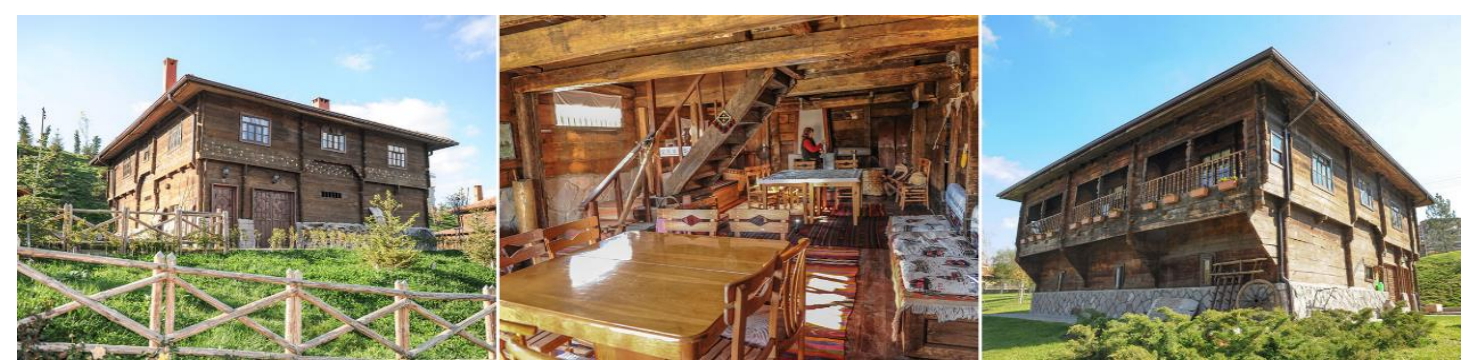

Şekil 2. Çantı evler (Anonim, 2019)

6 | $\mathrm{P}$ a g e

www.iiste.org 
Su Değirmeni: Tarihi süreç içinde Anadolu'da yaşayan medeniyetlerin en önemli yapılarından biri olan su değirmenleri, kırsal yerleşimlerde yer alan ve bölgenin yerel halkının temel besin kaynaklarından olan mısır ve buğdayın öğütmesinin yanı sıra; beslediği hayvanlarının yiyeceği olan tahıl türlerinin öğütülmesi amacıyla da kullanılmaktadır. Türk kültüründe, bireylerin kendi temel ihtiyaçlarını karşılamasının yanı sıra yetiştirdiği diğer canlıların besin teminine yönelik bu gereklilik, su değirmenlerini kırsal yerleşim alanlarının vazgeçilmez bir yapısı haline getirmiştir (Ceylan, 2014). Altınköy'de, değirmencilik geleneğinin yaşatılması ve yeni nesillere aktarılması amacı ile bir adet su değirmenine yer verilmiştir (Şekil 3).
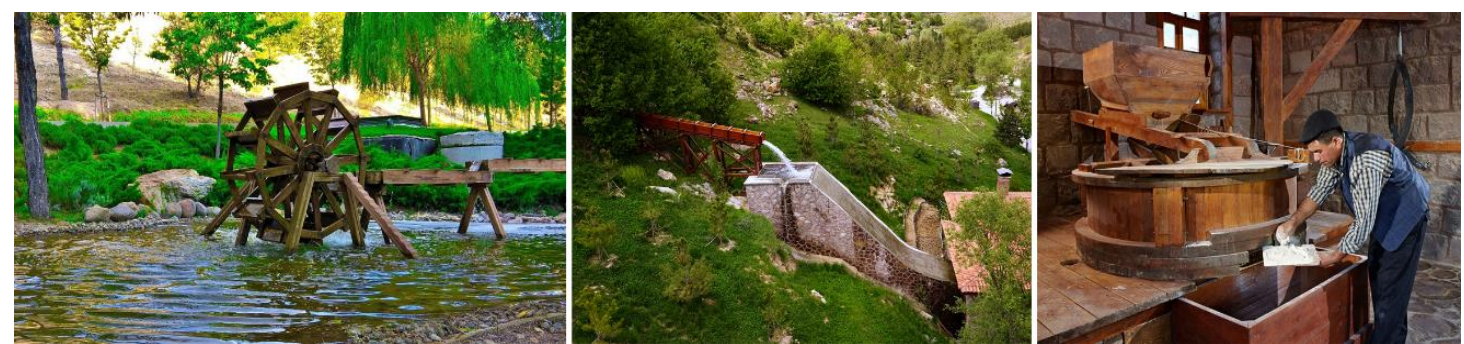

Şekil 3. Su değirmeni (Anonim, 2019)

Yel Değirmeni: Enerji üretmek için rüzgâr gücünden faydalanarak çalışan ve dört adet büyük pervanesi olan çarklı yapıdır. Tarihi süreç içinde yel değirmenleri, buğday öğütmek ve su pompalamak gibi farklı amaçlarla kullanılmış ve mekanik güç elde edilmiştir. Altınköy Açık Hava Müzesi’nin en önemli yapılarından biri olan ve buğdaydan un üretmek için kullanılan yel değirmeni; rüzgâr enerjisinden etkin biçimde yararlanması amacı ile köyün yüksek bir noktasına inşa edilmiştir. Değirmenin yapı parçaları ise; pervane, düver, çark, fener, balta demiri, kaldıraç sistemi, döner çatı, değirmen taşlarından oluşmaktadır (Şekil 4).
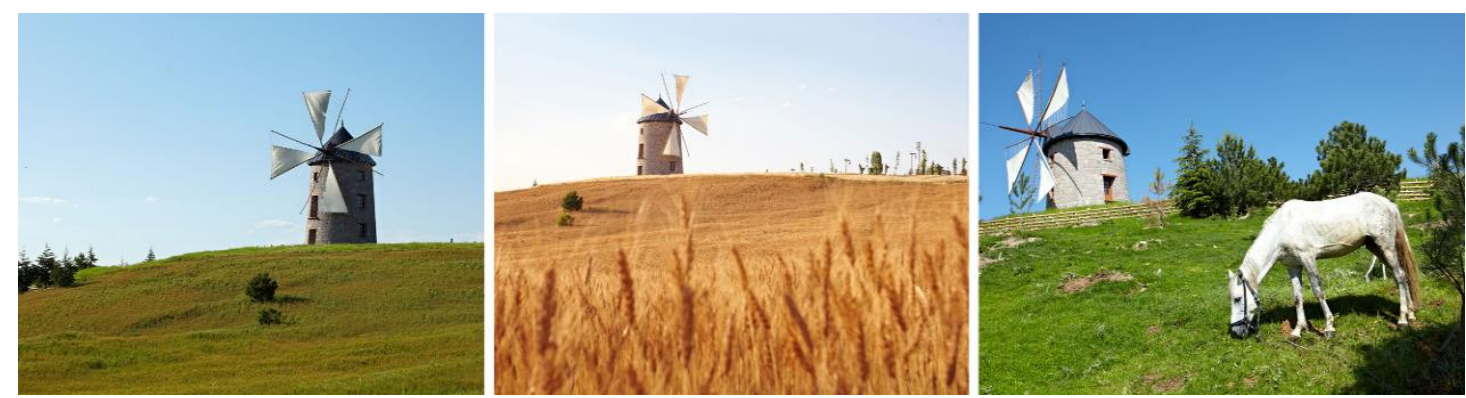

Şekil 4. Yel değirmeni (Anonim, 2019)

Asma Köprü: Geniş açıklıkların aşılması amacı ile en çok tercih edilen köprü tipi asma köprülerdir. Altınköy’de yer alan ve çelik halatların ve ahşabın yapı gereci olarak kullanıldığı asma köprünün uzunluğu 150 metre, yüksekliği ise 30 metredir. Köyde görsel peyzaj açısından alana en hakim bakı noktasının asma köprünün orta noktası olduğunu söylemek mümkündür (Şekil 5).
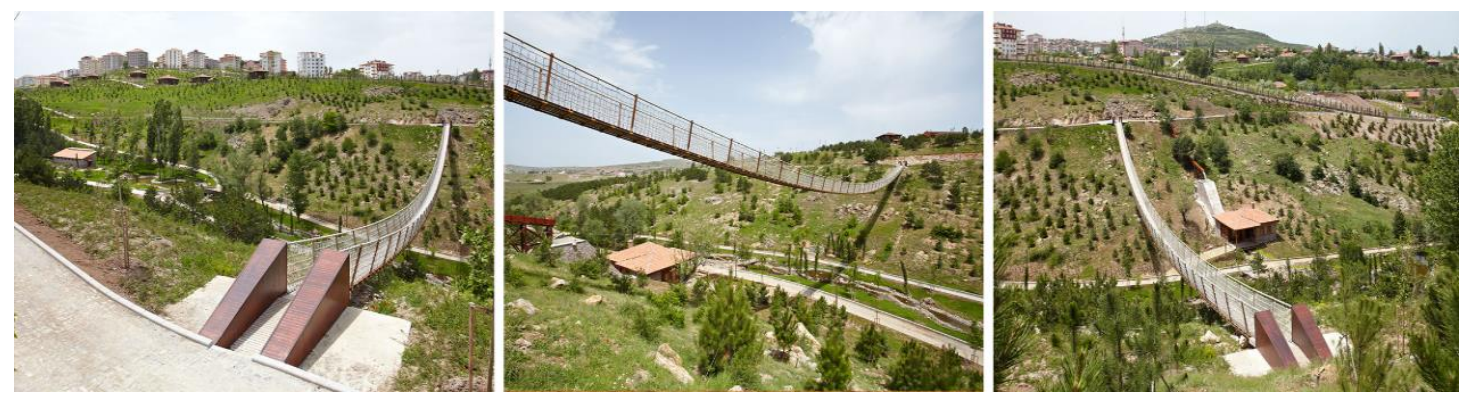

Şekil 5. Asma köprü (Anonim, 2019)

\subsection{Altınköy Açık Hava Müzesi’ndeki Arazi Örtüsü Değişiminin Tespit Edilmesi}

NDVI, yeşil alanları (görece biyokütle) gösteren bir görüntü oluşturulmasını sağlayan standart bir 
indekstir. Bu indeks, multispektral bir raster veri kümesinden iki bandın özelliklerinin kontrastının yanı sıra; kırmızı (IR) banttaki klorofil pigment absorpsiyonları ve yakın kızı̈ötesi (NIR) banttaki bitki materyallerinin yüksek yansıtıcılığından yararlanmaktadır. Analiz kapsamında kırmızı ve kızılötesi bant kombinasyonlarının kullanılacağı NDVI denklemi "NDVI = ((IR - R)/(IR + R))" olup; analiz sonucunda ortaya çıkan NDVI değeri; -1 ve 1 arasında değişmektedir. Bitki yoğunluğunun en düşük olduğu değer “-1" ile ifade edilirken; bitki yoğunluğunun en yüksek olduğu değer ise "1" ile ifade edilmektedir. Analiz sonucunda ortaya çıkan negatif değerler bulutlar, su ve karı temsil ederken; sıfıra yakın değerler kaya ve çıplak toprağ 1 temsil etmektedir. NDVI'nın çok düşük değerleri (0,1 ve altı); kaya, kum veya karların çorak alanlarına karşılık gelirken; orta değerler $(0,2$ ile 0,3$)$ çalı ve otlakları temsil etmekte; yüksek değerler $(0,6$ ila 0,8$)$ ise 1 lıman ve tropik yağmur ormanlarını göstermektedir (ESRİ, 2016). Araştırma kapsamında, kentsel dönüşüm alanı olan Altınköy Açık Hava Müzesi’ndeki arazi örtüsü değişiminin belirlenmesi amacı ile 2010 yılı Temmuz ayına ait Landsat 7 ETM+ görüntüsünde; yakın kızı̈ötesi (band 4) ve kırmızı (band 3) kombinasyonları kullanılarak NDVI analizi gerçekleştirilmiş; 2018 yılı Temmuz ayına ait Landsat 8 OLI/TIRS uydu görüntüsünden ise, yakın kızı̈ötesi (band 5) ve kırmızı (band 4) kombinasyonları kullanılarak çalışma alanının NDVI değerleri tespit edilmiştir (Şekil 6 ve Şekil 7).

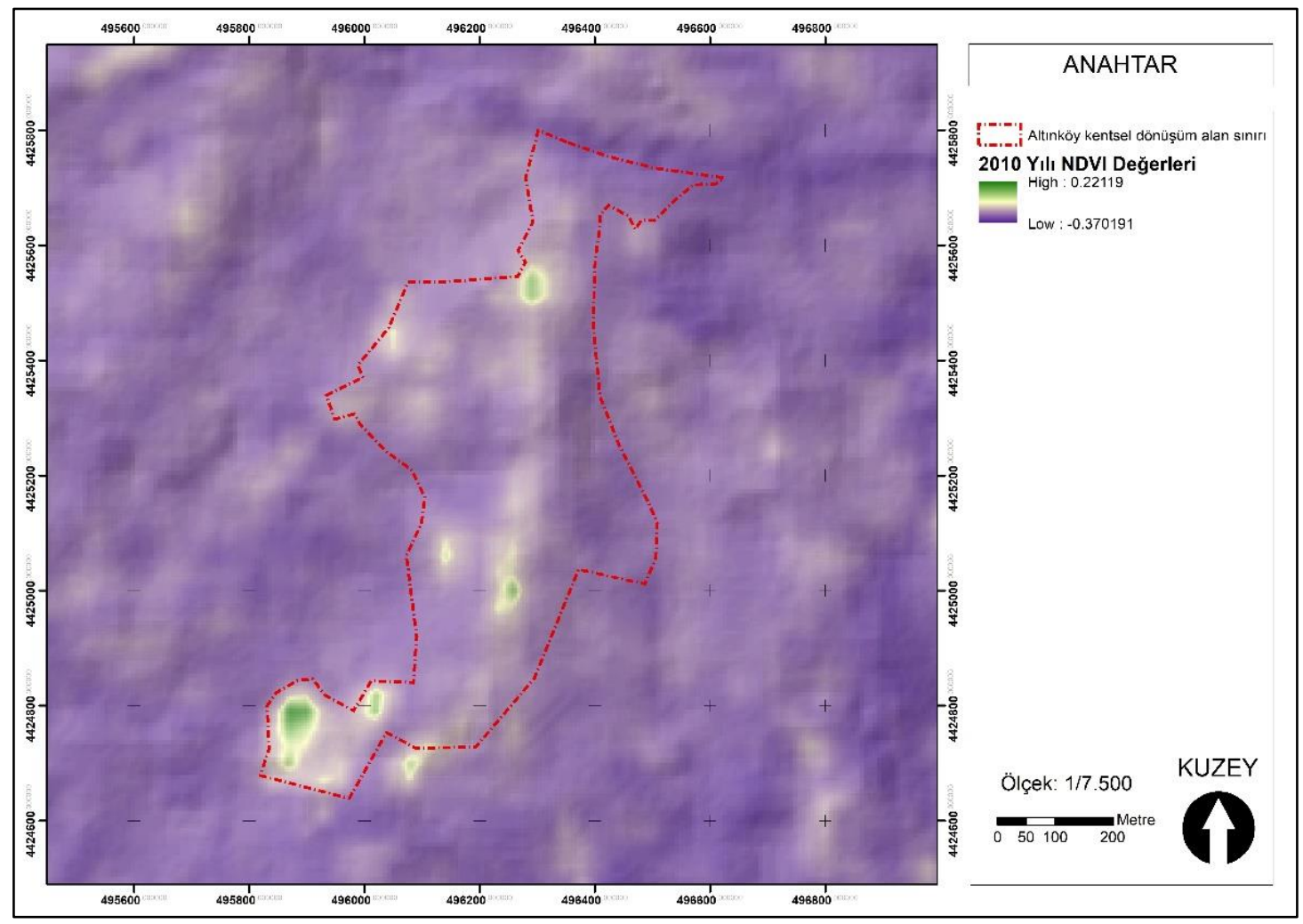

Şekil 6. Altınköy Açık Hava Müzesi 2010 yılı NDVI analizi (Orijinal, 2019) 


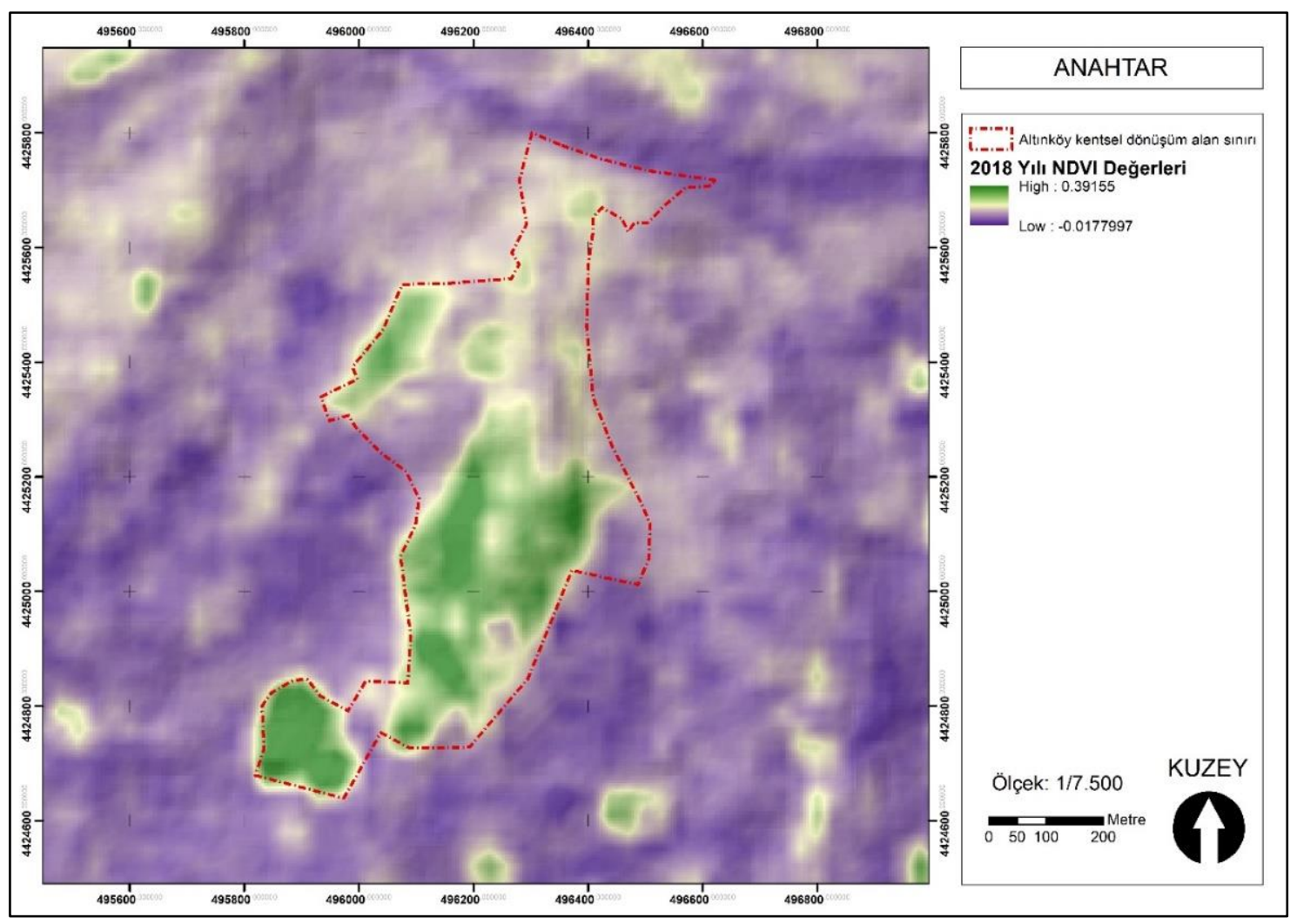

Şekil 7. Altınköy Açık Hava Müzesi 2018 yılı NDVI analizi (Orijinal, 2019)

2010 Yılı Temmuz ayına ait analiz sonucunda; NDVI değerinin -0.37 ile -0.22 arasında olduğu tespit edilmiştir. NDVI değerleri -0.37 - 0.2 arasında olan değerler kaya, kum veya çorak alanları oluştururken 0.2 'nin üzerindeki değerler ise yeşil alanları ifade etmektedir. Elde edilen iki kategorinin de alan (ha) hesabı yapılmıştır. 2018 Yı1ı Temmuz ayına ait analiz sonucunda ise; NDVI değerinin -0.01 ile 0.39 arasında olduğu tespit edilmiştir. NDVI değerleri -0.01-0.2 arasında olan değerler kaya, kum veya çorak alanları oluştururken 0.2'nin üzerindeki değerler ise yeşil alanları ifade etmektedir. Elde edilen 2 kategorinin de alan (ha) hesabı yapılmıştır (Tablo 3). Çalışma alanının 2000 yılındaki yeşil alan miktarı 1.17 hektar iken; kentsel gelişme nedeni ile 2018 yılında yeşil alan miktarının yaklaşık 15 kat artarak, 17.93 hektara yükseldiği tespit edilmiştir.

Tablo 3. Yeşil alan miktarındaki değişim

\begin{tabular}{lcc}
\hline & \multicolumn{2}{c}{ Büyüklük (ha) } \\
\cline { 2 - 3 } Uydu Görüntüsü/Yıı/Ay & $\begin{array}{c}\text { Kaya, kum veya çorak alanlar } \\
\mathbf{( - 0 . 9 - 0 . 2 )}\end{array}$ & $\begin{array}{c}\text { Yeşil alanlar } \\
\mathbf{( 0 . 2}-\mathbf{0 . 9})\end{array}$ \\
\hline $\begin{array}{l}\text { Landsat } 7 \text { ETM+/ } \\
\mathbf{2 0 0 0} / \text { Temmuz }\end{array}$ & 33.79 ha & 1.17 ha \\
\hline $\begin{array}{l}\text { Landsat } 8 \text { OLI/TIRS / 2018 / } \\
\text { Temmuz }\end{array}$ & 17.03 ha & 17.93 ha \\
\hline Değişim & & 16.76 ha artmış \\
\hline
\end{tabular}

\subsection{Altınköy Açık Hava Müzesi’nin Turizm Potansiyelinin Değerlendirilmesi}

SWOT analizi çalışma alanının güçlü ve zayıf yönlerinin belirlemesi ve dış faktörlerden kaynaklanan fursat ve tehditleri saptamak için kullanılan bir değerlendirme yöntemidir. İç ve dış faktörler dikkate alınarak, var olan güçlü yönler ve firsatlardan en üst düzeyde yararlanacak, zayıf yönlerin ve tehditlerin etkisini en aza indirecek plan, strateji ve tasarım önerileri geliştirilmek amacı ile gerçekleştirilmektedir. Bu kapsamda, SWOT Analizi ile Altınköy Açık Hava Müzesi'nin turizm potansiyelinin saptanması için güçlü, zayıf yönleri ve diş faktörlerin etkisi ile oluşabilecek firsatlar ve tehditler tespit edilmiştir (Tablo 4 ve tablo 5). 
Tablo 4. Altınköy Açık Hava Müzesi'nin SWOT Analizi (Dışsal Faktörler)

\section{DIŞSAL FAKTÖRLER}

Firsatlar (Opportunities)

- Açık Hava Müzesi olması

- Başkent Ankara'da yer alması

- Bölgedeki kentsel dönüşüm faaliyetlerinin devam ediyor olması

- Düşük hava kirliliği

- İl genelinde farklı amaçlı düzenlenen festival ve etkinlikler

- Yöre ve çevresinin geleneksel tarım ve ürünlerine yönelik artan tüketici talebi

\section{Tehditler (Thereats)}

- Genel anlamda turizm bilincinin eksikliği

- Düşük ücretle çalışırılan deneyimsiz elemanlar

- Tur güzergâhlarının programında yer almamas1

- Bölgede dağınık ve plansız yerleşim alanlarının olmasi

- Bölgesel anlamda turizm potansiyeli ve imajının zayıf olması

- Altındağ İlçesi'nde suç oranın ve güvenlik düzeyinin düşük olması

\section{IÇSEL FAKTÖRLER}

\section{Güçlï Yönler (Stranghts)}

- Ankara'nın coğrafi konumu

- Tarihi kent merkezi'ne uzak olması

- Farklı yerleşimlere ait kültür varlıklarının bulunması (Geleneksel konut dokusu, anıt yapilar1)

- Su kaynaklarının varlığı

- Ekoturizme uygun iklim koşulları

- Ulaşım altyapısı, erişilebilirlik (Karayolu ve hizlı tren)

- Ekoturizm amaçlı kullanılabilecek özelliklere sahip olması

- Doğa yürüyüşü için uygun topografik yapının varlığ

- Yayla turizmi açısından uygun alanların varlı̆̆ 1

- İl yönetiminin turizm sektörünü öncelikli sektör olarak görmesi

- Asma köprü ve yel değirmeni gibi zengin manzara ve seyir noktalarının bulunması

- Yaban hayatı ve yaşam alanlarının varlığı

- Bitki örtüsünün çeşitliliği ve ağaçlandırma alanlarının

- $\quad$ Tarihi öneme sahip inanç ve kültür turizmi açısından zengin kaynaklara sahip olması

- Su kıyısı kullanımlarına olanak sağlaması

- Geleneksel el sanatlarının varlığı

- Geleneksel yemeklerinin gastronomi turizmi için potansiyel oluşturması

\section{Zayıf Yönler (Weaknesses)}

- Havaalanına uzak olması

- Geleneksel yaşam biçiminin ulusal ve uluslararası ölçekte yeteri kadar tanitilamamas1

- Bölgede gerçekleştirilebilecek turizm faaliyetlerini profesyonel açıdan dikkate alan kurum ve kuruluşların olmaması

- Turist bilgilendirme biriminin olmamas

- Turizm açısından toplum bilincinin yetersiz olmas1

- Konaklama tesislerinin olmamasi

- Turizm sektörüne ilişkin sosyal altyapı eksikliği

- Rekreasyon alanlarında günübirlik turizme bağlı oluşan çevresel ve görsel kirlilik

- Altınköy'e ilişkin turizme yönelik tanıtım ve pazarlamanın yetersizliği

- Geleneksel el sanatlarının tanitım ve pazarlama yetersizliği

- Ekoturistik tesis ve alt yapı eksikliği

- Yerel/Yöresel sertifikalı ürünlerin geliştirilmemiş olması

- Turizm firmalarınnın yetersizliği ve tur organizasyonundaki eksiklikler

- Ekoturizm ve diğer turizm faaliyetleri için eğitimli personel eksikliği

- $\mathrm{Su}$ kiyıs1 rekreasyon faaliyetlerinin geliştirilememiş olması

- Kapalı toplumsal yapı

- Yabancı turistler için bölge halkının yabancı dil bilgisinin yetersiz olması 


\section{Sonuç}

Kentsel ve kırsal peyzaj tasarım çalışmalarında, peyzaj mimarının mekâna yansıtmak istediği temayı; kentsel donatı, heykel, sokak, cadde, mahalle, kent gibi farklı pek çok ölçekde ifade edebilmektedir. Bu noktada önemli olan; renk, malzeme, kavram, bitki, sanat akımı veya dönemi kullanımının yanı sıra kültür ve coğrafyanın etkisi gibi kriterlere dikkat edilmesidir. Peyzaj mimarı ve mimar, kullanıcının algılamasını istediği temayı doğru renk, 1şık, malzeme, doku, kavramı kullanmak sureti ile gerçekleştirirse, ancak o zaman iletmek istediği mesaj, duygu yerine ulaşmış olacaktır (Yurttaş, 2010).

Tarihi süreç içinde gerçekleştirilen kentsel dönüşüm uygulamalarında, kentsel yaşam kalitesini ve kentteki yeşil alan miktarını arttırmanın aksine kentsel alanlarda yer alan flora ve fauna varlığına dolayısı ile kent ekolojisine zarar veren, doğal ve kültürel miras alanlarının dikkate alınmadığ 1 tasarımlar gerçekleştirilmektedir. Kentsel dönüşüm alanlarında gerçekleştirilecek tasarımlar ile dinamik ve doğa dostu tematik mekânlar oluşturmak mümkündür. Diğer bir ifade ile bu alanların peyzaj tasarımında ele alınan temanın, kent kimliğini ve kentin estetik değerlerini arttırması beklenmektedir. Kentsel dönüşüm alanlarında kullanılan canlı ve cansız malzemenin yanı sıra kent kimliğini koruyan sürdürülebilir peyzaj tasarım yaklaşımlarının da benimsenmesi, kentin sahip olduğu nitelikler açısından büyük önem taşımaktadır. Bu yaklaşımları benimseyen tematik peyzaj tasarımları sayesinde; kentlerin doğal, kültürel ve tarihi değerleri korunup, yaşam kalitesi artırılırken, çevre ve kent estetiği bağlamında da katkılar sağlanmış olacaktır.

2015 Yılında hizmete giren Altınköy Açık Hava Müzesi, Ankara'da yer alan bir kentsel dönüşüm alanı olup; kentsel dönüşüm alanlarında gerçekleştirilebilecek "kültür" temalı bir peyzaj tasarım uygulamasına örnek olarak gösterilebilir. Köyde kullanılan yap1 gereçlerinin ve doğa dostu peyzaj tasarım uygulamaların yanı sıra kırsal yerleşim karakterini de yansıtan etkinliklere yer vermesi, kısaca "yaşayan köy” olarak nitelendirilebilmesi açısından önemli ve özgün bir örnektir. Unutulmamalıdır ki, kentsel çevreler için yapılan her tasarım, kent estetiği, kent kimliği ve kentin turizm potansiyeli açısından çok önemlidir. Ancak bu süreçte, kentsel dönüşümm uygulamalarının yapıldığı kentlerde, kentsel yaşam kalitesinin arttırılması için kişi başına düşen açık ve yeşil alan miktarının en az $9 \mathrm{~m}^{2}$ olması bir zorunluluktur. Bu nedenle gelecekte gerçekleştirilecek kentsel dönüşüm uygulamalarında; kentin kültür ve kimlik bileşenleri ve kent estetiğinin yanı sıra doğa dostu peyzaj öğelerine ve ekolojik temele dayalı peyzaj alanlarına yer veren temaların uygulanması önemli bir konudur.

\section{References}

Abercrombie, S. (1990). Philosophy of interior design. Harper \& Row, 17-33, New York.

Altın, B., (2015). Mekân Tasarımında Tema: Tematik Konut Örnekleri. Yükseklisans Tezi. Atılım Üniversitesi, Sosyal Bilimler Enstitüsü, İç Mimarlık Ve Çevre Tasarımı Ana Bilim Dalı, 170, Ankara.

Ataöv, A. ve Osmay, S. (2007). Türkiye'de Kentsel Dönüşüme Yöntemsel Bir Yaklaşım. METU JFA, (24:2) 57-82.

Anonim (2019). Altınköy Açık Hava Müzesi. Web Sitesi: http://www.altinkoy.tc/, Erişim Tarihi: 27.02.2019.

Ceylan, S. (2014), “Kaybolmakta Olan Bir Kırsal Maddi Kültür Örneği: Su Değirmenleri (Ăglasun Örneği)”, Doğu Coğrafya Dergisi, Ocak (January) S. 31, s. 65-82.

Codur, M. B. (2010). Tematik Mekân Düzenlemelerinde Grafik Tasarım Uygulamaları. Sanatta Yeterlik Tezi, Hacettepe Üniversitesi Sosyal Bilimler Enstitüsü, 172, Ankara.

Erzurumlu-Sandal G., Yıldı, N. E. ve Kahveci, B. 2017. The Evaluation of Active Green Sites For Recreation: Bor Case. Eurasian Journal of Agricultural Research, 1 (1): 48-56.

ESRİ (2016). NDVI Function. Web Sitesi: http://desktop.arcgis.com/en/arcmap/10.3/managedata/raster-and-images/ndvi-function.htm, Erişim Tarihi: 06.12.2018.

11 | P a g e

www.iiste.org 
Keleş, R. (2004) Kentsel Dönüşümün Tüzel Altyapısı, H. B. Tuna (Editör), Dosya: Kentsel Dönüşüm ve Katılım, Mimarist Dergisi, TMMOB Mimarlar Odası İstanbul Büyükkent Şubesi, 4(12), 73 75.

Polat, S. ve Dostoğlu, N. (2007). Kentsel Dönüşüm Kavrami Üzerine: Bursa'da Kükürtlü Ve Mudanya Örnekleri. Uludağ Üniversitesi Mühendislik-Mimarlık Fakültesi Dergisi, 12(1), 61-76.

Sümerkan, M. R. (2011). Anlatım Açısından Konu ve Tema “Görsel Sanatlar”. Web Sitesi: http://www.bayta n.org/prak/konutema.html, Erişim Tarihi: 04.12.2015.

TDK (2006). Genel Türkçe Sözlüğü. Web Sitesi: http://www.tdk.gov.tr/index.php?option=com_gts\& arama=gts\&guid=TDK.GTS.56616f07439360.0903557, Erişim Tarihi: 04.12.2015.

Thomas, S. (2003) A Glossary of Regeneration and Local Economic Development, Manchester: Local Economic Strategy Center.

Yurttaş, N. B. (2010). İç Mekan Tasarımında “Tema” Kavramı ve “Tematik Mekan” Olgusunun Örnekler Üzerinde Analizi. Yükseklisans Tezi, Mimar Sinan Güzel Sanatlar Üniversitesi, Fen Bilimleri Enstitüsü, İç Mimarlık Ana Bilim Dalı, İç Mimarlık Programı, 199, İstanbul. 